\title{
Morphological and mechanical characterization of chitosan-calcium phosphate composites for potential application as bone-graft substitutes
}

Guilherme Maia Mulder van de Graaf, Andre Luis do Valle De Zoppa, Rodrigo Crispim Moreira, Sylma Carvalho Maestrelli, Rodrigo Fernando Costa Marques, Maria Gabriela Nogueira Campos*

\begin{abstract}
Introduction: Bone diseases, aging and traumas can cause bone loss and lead to bone defects. Treatment of bone defects is challenging, requiring chirurgical procedures. Bone grafts are widely used for bone replacement, but they are limited and expensive. Due to bone graft limitations, natural, semi-synthetic, synthetic and composite materials have been studied as potential bone-graft substitutes. Desirable characteristics of bone-graft substitutes are high osteoinductive and angiogenic potentials, biological safety, biodegradability, bone-like mechanical properties, and reasonable cost. Herein, we prepared and characterized potential bone-graft substitutes composed of calcium phosphate (CP) - a component of natural bone, and chitosan (CS) - a biocompatible biopolymer. Methods: CP-CS composites were synthetized, molded, dried and characterized. The effect of drying temperatures $\left(38\right.$ and $\left.60^{\circ} \mathrm{C}\right)$ on the morphology, porosity and chemical composition of the composites was evaluated. As well, the effects of drying temperature and period of drying (3, 24, 48 and 72 hours) on the mechanical properties - compressive strength, modulus of elasticity and relative deformation-of the demolded samples were investigated. Results: Scanning electron microscopy and gas adsorption-desorption analyses of the CS-CP composites showed interconnected pores, indicating that the drying temperature played an important role on pores size and distribution. In addition, drying temperature have altered the color (brownish at $60{ }^{\circ} \mathrm{C}$ due to Maillard reaction) and the chemical composition of the samples, confirmed by FTIR. Conclusion: Particularly, prolonged period of drying have improved mechanical properties of the CS-CP composites dried at $38{ }^{\circ} \mathrm{C}$, which can be designed according to the mechanical needs of the replaceable bone.
\end{abstract}

Keywords: Chitosan, Calcium phosphate, Bone-grafts, Substitutes, Mechanical properties.

\section{Introduction}

Bone tissue is a composite material composed by a combination of mineral phase (hydroxyapatite), organic components (collagen and proteins) and water (Boskley, 2013). The proportion of these components may vary by age, gender, site and disease (Boskley, 2013). Diseases, such as osteoporosis, and traumas can cause bone loss or bone fracture. Treatment of bone defects still is a challenge for orthopedic surgeons, especially for large ones (Oryan et al., 2013). Bone-grafts are the traditional treatment under these special circumstances (Sumner-Smith, 2002). Although autografts are the gold standard method of bone replacement, they have some disadvantages, such as donor-site complications and morbidity (Calori et al., 2011). Silver treatment of defects are the allografts. However, limitations of allografts include potential transmission of diseases and reabsorption/rejection (Moshiri and Oryan, 2012). Another alternative for replacement are the xenografts, but their limitations are similar to that

*e-mail: mgabriela@unifal-mg.edu.br

Received: 09 June 2015 / Accepted: 06 October 2015 of allografts. Nevertheless, further than higher rejection rate, the main concern of xenografts are transmission of unknown zoonotic diseases from animals (Moshiri and Oryan, 2012).

To overcome the subjects of bio-based grafts, synthetic grafts have been developed due to their unlimited supply and no disease transmission (Amini et al., 2012). The graft should support, reinforce and organize the regenerating tissue and interact with extracellular matrix components, growth factors, and cell receptors (Khan et al., 2008; Madihally and Matthew, 1999). Other desirable characteristics of synthetic grafts are high osteoinductive and angiogenic potentials, biological safety, biodegradability, bone-like mechanical properties, and reasonable cost (Amini et al., 2012).

Polymeric, ceramic, metal and composite materials have been extensively studied as bone-graft substitutes (Dabrowski et al., 2010; Hing et al., 2007; Hutmacher, 
2000; Li et al., 2014). Moreover, biodegradable polymeric matrices have been investigated as temporary bone-grafts substitutes due to their integration with growing tissue during the healing process (Armentano et al., 2010). Although many materials have been used as synthetic bone-grafts, none of them has reached the three essential criteria for ideal bone replacement: mechanical properties, biodegradability, and osteoinductivity (Bonher et al., 2012). Thus, continuous research has being developed toward to more adequate bonegraft substitutes (Bonher et al., 2012). Herein, we proposed a composite material based on chitosan and calcium phosphate with adjustable mechanical properties for potential application as bone-graft substitute.

Chitosan (CS) is a biopolymer obtained by the deacetylation of chitin, which is a naturally abundant polysaccharide (Pillai et al., 2009). CS has been receiving attention because of its interesting properties, such as biocompatibility, biodegradability and bioactivity (Martino et al., 2005; Rinaudo, 2006). Recent studies demonstrated that CS can induce angiogenesis and osteogenesis and act as a temporary bone substitute (Spin-Neto et al., 2008). In addition, CS can be combined with several materials, such as polymers (PMMA, PCL, and PLLA), bioceramics (hydroxyapatite), growth factors and other organic/inorganic compounds, for applications in bone regeneration (Venkatesan et al., 2014; Zhang and Zhang, 2002).

Calcium phosphate (CP) is the main constituent of hydroxyapatite, the bone mineral that strengthens the mechanical resistance of the organic matrix (Bonjour, 2011). Sintered hydroxyapatite has been used in synthetic bone-graft substitutes due to its chemical similarity to bone mineral. However, the resorption rate of sintered hydroxyapatite is very low and may compromise biodegradation of the graft (Bonher et al., 2012). In order to prepare fast-resorbable bone-graft substitutes, hydroxyapatite has been replaced for more-soluble, biphasic $\mathrm{CP}$, such as alpha and beta tri-calcium phosphate (Hu et al., 2014).

Therefore, the combination of CS and CP can produce an interesting biodegradable composite material with the flexibility of polymers and the hardness of minerals. In this work, we prepared mechanical properties-adjustable CS-CP composites for potential application as resorbable bone-grafts substitutes. These CS-CP composites can be molded in any shape and designed according to the mechanical needs of the bone to be replaced.

\section{Methods}

\section{Materials}

Unless specified, all materials were purchased from Sigma-Aldrich (St. Louis, MO/USA) and used as received.

\section{Formulation of CS-CP composites}

High molecular weight chitosan with degree of deacetylation superior to $75 \%, \beta$-tri-calcium phosphate, citric acid, dextrose and distilled water were used to prepare the composites. The ratio $(\mathrm{m} / \mathrm{m})$ of components: $2.6 \%$ of chitosan, $4.6 \%$ of distilled water, $31.5 \%$ of citric acid, $21.9 \%$ of dextrose and $39.4 \%$ of $\beta$-tri-calcium phosphate was obtained by the following methodology:

\section{Preparation of hydrogel}

Citric acid $(36.5 \mathrm{~g})$ was dissolved in $12.5 \mathrm{ml}$ of distilled water in order to prepare an acid solution. Then, a hydrogel was obtained by dissolving chitosan $(1.0 \mathrm{~g})$ in the acid solution, under stirring at room temperature.

\section{Addition of solid components}

In a porcelain mortar, $1 \mathrm{~g}$ of hydrogel, $125 \mathrm{mg}$ of chitosan, $1.0 \mathrm{~g}$ of citric acid and $1.2 \mathrm{~g}$ of dextrose were manually homogenized with a pestle for 5 minutes at room temperature to produce a pasty mass. Then, $650 \mathrm{mg}$ of $\beta$ - tri-calcium phosphate were added for each gram of pasty mass in order to obtain a firm mass (but malleable).

\section{Drying}

A cylindrical Teflon ${ }^{\circledR}$ mold $(6 \mathrm{~mm}$ diameter and $12 \mathrm{~mm}$ height - NBR ISO 5833) (Associação..., 2004) opened on both ends was placed on a Teflon ${ }^{\circledR}$ disc and then filled with the previously obtained mass. Another Teflon ${ }^{\circledR}$ disc was used to cover the filled mold and a clamp was used to press the three pieces-system in order to obtain uniform specimens. The system was placed in an oven with air circulation (Nova Ética/Brazil) at 38 or $60{ }^{\circ} \mathrm{C}$ for 150 minutes. After this, samples were demolded and namely as C38 (sample dried at $38^{\circ} \mathrm{C}$ ) and as $\mathrm{C} 60$ (sample dried at $\left.60{ }^{\circ} \mathrm{C}\right)$.

\section{Macroscopic evaluation}

Samples C38 and C60 were macroscopically evaluated by color, dimensional stability and handling. 


\section{Fourier Transform Infrared Spectroscopy (FTIR)}

FTIR spectra of CS, C38 and C60 were recorded in a TENSOR27 Spectrometer (Bruker/USA) in the $500-2000 \mathrm{~cm}^{-1}$ spectra range. After demolded, samples $\mathrm{C} 38$ and $\mathrm{C} 60$ were ground in a mortar with a pestle and the powders were analyzed. Chitosan in powder form was used to record CS spectrum. All spectra were recorded at room temperature.

\section{Scanning Electron Microscopy (SEM)}

Surficial and sectional morphology of C38 and C60 samples analyzed by SEM. Samples were blade-cut in order to acquire cross sectional images. All samples were gold spin coated $(16 \mathrm{~nm})$ in a sputter coater model SCD 050 (Bal-tec/USA) for 60s, $2 \times 10^{-2} \mathrm{~Pa}$ at $24{ }^{\circ} \mathrm{C}$ and dried under vacuum. SEM images of samples were taken in a JSM 7500-F Field Emission Scanning Electron Microscope (JEOL/Japan).

\section{BET/BHJ Surface area and Pore size}

Samples were dried under vacuum and the specific surface area was measured with an ASAP 2010 instrument (Micromeritics/USA), using a multiple point Brunauer-Emmet-Teller (BET) method (nitrogen adsorption). Barrett-Joyner-Halenda (BJH) analysis was employed to determine specific pore volume by nitrogen adsorption and desorption techniques.

\section{Mechanical testing}

Compression tests were performed on ten pieces of each of the two sample groups $\mathrm{C} 38$ and $\mathrm{C} 60$. To evaluate the effect of drying temperature and period of drying on mechanical properties demolded samples $\mathrm{C} 38$ and C60 were kept in an oven at 38 and $60^{\circ} \mathrm{C}$, respectively. Then, compression tests were performed within 3, 24,

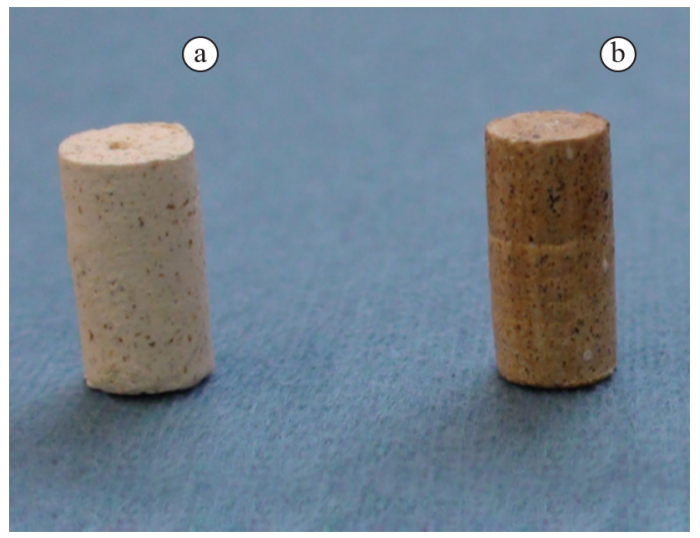

Figure 1. Demolded CS-CP composites after drying for 150 minutes at (a) $38^{\circ} \mathrm{C}$ - sample $\mathrm{C} 38$; and (b) at $60{ }^{\circ} \mathrm{C}$ - sample $\mathrm{C} 60$.
48 and 72 hours. All tests were performed in a KE 3000 MP Universal Testing Machine (KRATOS/USA) using air atmosphere at room temperature. The samples were subjected to axial compressive load of $3,000 \mathrm{kgf}$ and a rate of $5 \mathrm{~mm} / \mathrm{min}$. Load and displacement data were used to determine the compressive strength, relative deformation and modulus of elasticity for each sample. To determine the statistical significance of the parameters, differences were compared using a two-way analysis of variance (ANOVA) calculated using $\mathrm{SAS}^{\circledR}$ software. Tukey's honestly significant difference method was also used. For measurements, $\mathrm{p}<0.05$ was considered significant.

\section{Results}

\section{Macroscopic evaluation}

Figure 1 shows the final shape of the samples after drying for 150 minutes at $38^{\circ} \mathrm{C}$ (a) and $60{ }^{\circ} \mathrm{C}$ (b). Both samples (C38 and $\mathrm{C} 60$ ) showed dimensional stability and were easily removed from the mold. Regarding to the color aspect, browning of sample C60 was observed.

\section{FTIR}

FTIR spectra of samples C38, C60 and CS are shown in Figure 2. As expected, we found different FTIR spectra for CS, C38 and C60 samples. The main differences observed were at $1600 \mathrm{~cm}^{-1}$ and $900 \mathrm{~cm}^{-1}$, where characteristic peaks of primary amines can be found (N-H stretch and N-H wag, respectively). As control, CS spectrum showed a peak at $1650 \mathrm{~cm}^{-1}$, which was slightly shifted to $1658 \mathrm{~cm}^{-1}$ in $\mathrm{C} 38$ spectrum, but completely disappeared in C60 spectrum (black arrow). In the same way, the peak observed at $889 \mathrm{~cm}^{-1}$ in CS spectrum can be found at $881 \mathrm{~cm}^{-1}$ in C38 spectrum, then again has disappeared in C60 spectrum (gray arrow). The characteristic peak of carboxylic acid salts (carboxylates) around $1500 \mathrm{~cm}^{-1}$ was observed in both C38 and C60 IR spectra. These strong peaks at $1510 \mathrm{~cm}^{-1}$

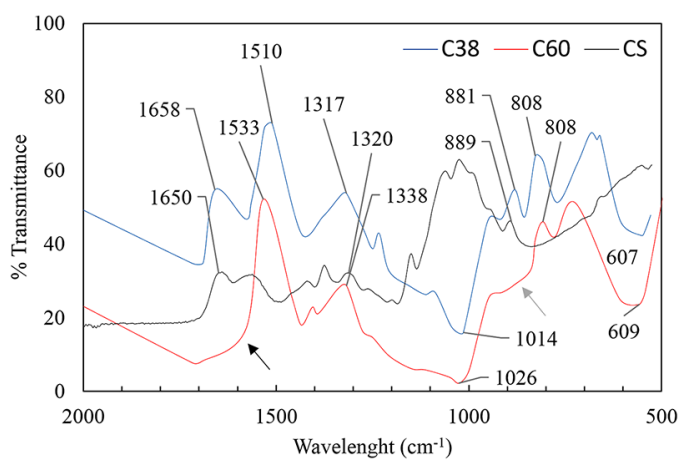

Figure 2. FTIR Spectra of CS (black), C38 (blue) and C60 (red). 
and $1533 \mathrm{~cm}^{-1}(\mathrm{C} 38$ and $\mathrm{C} 60$, respectively) are due to the formation of citrate salts of CS in the presence of citric acid. In addition, intensive IR absorption bands of $\mathrm{PO}_{4}^{-3}$ group at $1000-1100 \mathrm{~cm}^{-1}$ and $560-600 \mathrm{~cm}^{-1}$ can be clearly observed in $\mathrm{C} 38$ and $\mathrm{C} 60$ spectra, confirming the presence of $\mathrm{Ca}_{3} \mathrm{PO}_{4}$ in these samples. Finally, the characteristic peak of C-C-C in-plane bend assigned at $808 \mathrm{~cm}^{-1}$ in both $\mathrm{C} 38$ and $\mathrm{C} 60$ spectra is due to the pyranose ring of dextrose, which is another component of the analyzed samples.

\section{SEM}

The micrographs of samples C38 and C60 are shown in Figure 3. Surficial and cross sectional images were taken in order to evaluate the morphology of the samples. As observed in Figure 3a, b, surficial morphology of samples C38 and C60 is similar and flake-shape crystals can be observed in both samples.
However, superficial porosity and pore size of sample C60 appears to be higher than C38. In Figure 3c, d, cross sectional morphology of samples is shown. As well as in surficial morphology, flake-shape crystals were also observed inside of the samples. Then again, the number and the size of pores found in the interior of sample C60 appears larger than those found in sample C38.

\section{BET/BJH Surface area and Pore size}

The porosity of samples was analyzed by nitrogen adsorption-desorption methodology. Table 1 summarizes the results of BET specific surface area and BJH specific pore volume analyses of samples $\mathrm{C} 38$ and C60. C60 showed higher surface area and specific pore volume as compared to the $\mathrm{C} 38$. These results were in accordance to those observed in the SEM images (Figure 3).
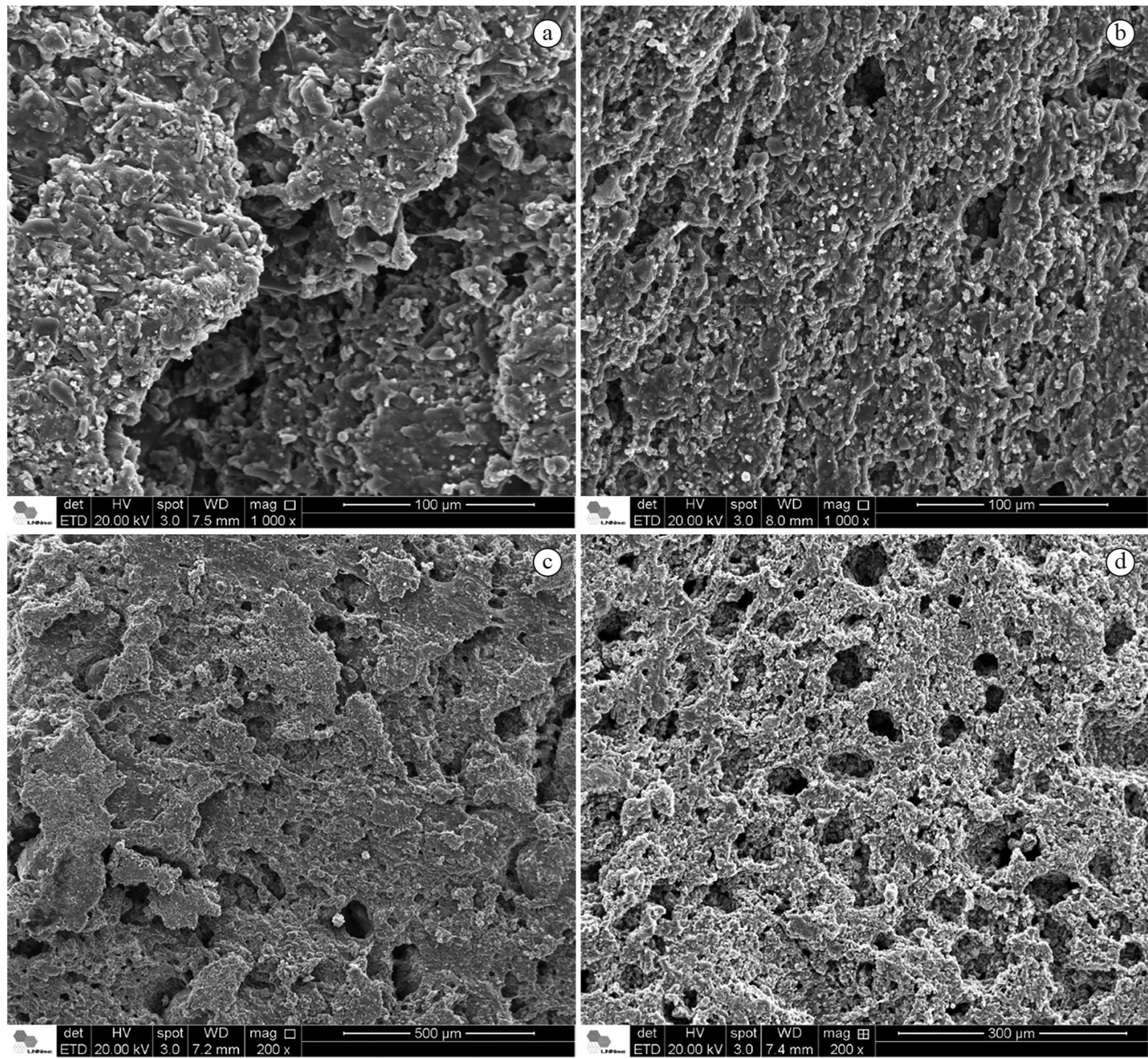

Figure 3. SEM images of CS-CP bone-grafts substitutes. (a) Surficial image of sample C38; (b) Surficial image of sample C60; (c) Crosssectional image of sample C38; and (d) Cross-sectional image of sample C60. 
Table 1. Specific surface area and specific pore volume of samples $\mathrm{C} 38$ and $\mathrm{C} 60$, calculated by BET and BJH methods, respectively.

\begin{tabular}{ccc}
\hline Sample & $\begin{array}{c}\text { Specific surface area } \\
\left(\mathbf{m}^{2} / \mathbf{g}\right)\end{array}$ & $\begin{array}{c}\text { Specific pore volume } \\
\left(\mathbf{c m}^{3} / \mathbf{g}\right)\end{array}$ \\
\hline C38 & 1.0404 & 0.000118 \\
C60 & 1.5319 & 0.000876 \\
\hline
\end{tabular}

\section{Mechanical testing}

The effects of drying temperature and period of drying on the mechanical properties of the samples were evaluated by compressive strength, modulus of elasticity and relative deformation measurements. Figures 4, 5 and 6 summarizes compressive strength, modulus of elasticity and relative deformation of C38 and C60 within 3, 24, 48 and 72 hours of demolded-drying at $38{ }^{\circ} \mathrm{C}$ and $60{ }^{\circ} \mathrm{C}$, respectively. As showed in Figure 4, a continuous increase on the compressive strength of $\mathrm{C} 38$ from 3 to 72 hours was observed. On the other hand, for sample C60, the compressive strength was only increased from 3 to 24 hours. From 24 to 48 hours, C60 kept the same compressive strength, but it was reduced from 48 to 72 hours. At 48 hours, samples C 38 and C60 showed similar compressive strength and only within 72 hours, C38 showed higher compressive strength than C60. In addition, C38 and C60 showed similar modulus of elasticity from 3 to 48 hours, then again C38 showed higher modulus of elasticity than C60 at 72 hours (Figure 5). The relative deformation of samples C38 and C60, showed in Figure 6, was similar at 3, 48 and 72 hours. Nevertheless, at 24 hours, C38 showed higher relative deformation than $\mathrm{C} 60$.

\section{Discussion}

We produced CS-CP composites for potential bone-graft substitutes by a three steps methodology. The CS-CP composites were made by adding the solid components (citric acid, dextrose, chitosan and $\beta$-tricalcium phosphate) to a previously prepared chitosan hydrogel. Before drying, the composite had clay-like consistency and could be molded into any desired shape. We used cylindrical molds in accordance to the Brazilian Standard - NBR ISO 5833 (Associação..., 2004) and samples were dried at $38{ }^{\circ} \mathrm{C}$ or $60{ }^{\circ} \mathrm{C}$. After unmolding, C38 and C60 showed dimensional stability and cylindrical shape (Figure 1). Moreover, browning of $\mathrm{C} 60$ was observed. The non-enzymatic browning of sample C60 can be attributed to the Maillard reaction, occurring between the amino groups of glucosamine (chitosan) and the carbonyl group (dextrose). The Maillard reaction between $\mathrm{CS}$ and various carbohydrates has been extensively studied (Chung et al., 2005; Kosaraju et al., 2010;

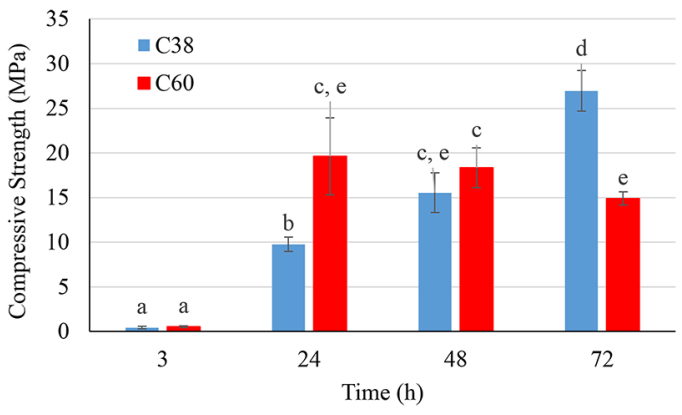

Figure 4. Compressive Strength of samples C38 and C60 after demolded-drying for $3,24,48$ and 72 hours at $38{ }^{\circ} \mathrm{C}$ and $60^{\circ}$, respectively. Different letters on averages mean statistically different values $(\mathrm{p}<0.05)$.

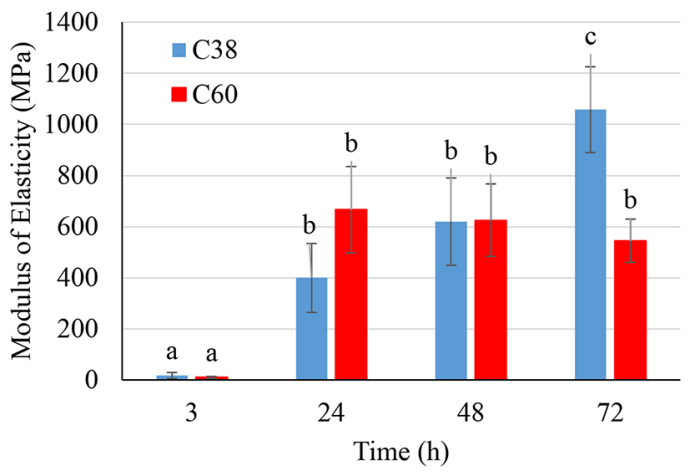

Figure 5. Modulus of Elasticity of samples C38 and C60 after demolded-drying for $3,24,48$ and 72 hours at $38^{\circ} \mathrm{C}$ and $60^{\circ}$, respectively. Different letters on averages mean statistically different values $(\mathrm{p}<0.05)$.

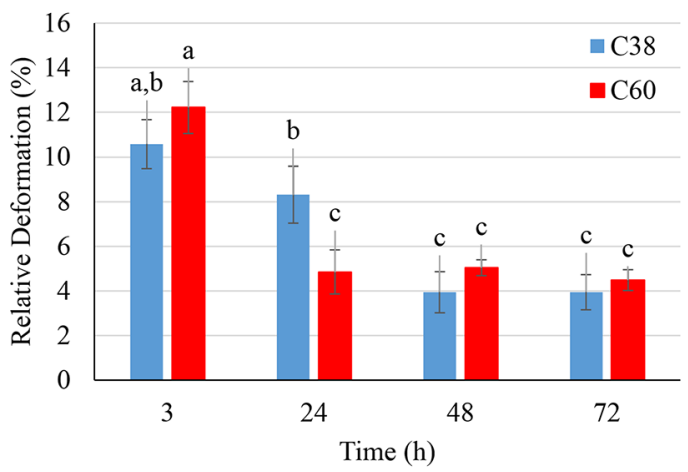

Figure 6. Relative deformation of samples $\mathrm{C} 38$ and $\mathrm{C} 60$ after demolded-drying for $3,24,48$ and 72 hours at $38^{\circ} \mathrm{C}$ and $60^{\circ}$, respectively. Different letters on averages mean statistically different values $(\mathrm{p}<0.05)$.

Umemura and Kawai, 2007). According to these studies, the browning rate depends on the reactional parameters, such as $\mathrm{pH}$, water activity and temperature (Chung et al., 2005; Kosaraju et al., 2010; Umemura and Kawai, 2007). Kosaraju et al. (2010) studied the effects of heating treatment and $\mathrm{pH}$ on the extent of the Maillard reaction by FTIR, Differential Scanning 
Calorimetry, Total Color Change and Oxygen Radical Absorbance Capacity (ORAC) Assay. They reported band shifts on the FTIR spectra of chitosan and chitosan-glucose conjugates, indicating the progress of the Maillard reaction.

We also carried out FTIR studies to identify the functional groups present in samples $\mathrm{C} 38$ and $\mathrm{C} 60$ (Figure 2). The absence of characteristic peak of N-H stretch in primary amines at $1650 \mathrm{~cm}^{-1}$ in $\mathrm{C} 60$ spectrum can be attribute to the partial consumption of amino groups during the Maillard reaction. In addition, the characteristic peak of amide (III) bond associated to $\mathrm{C}-\mathrm{N}$ stretch at $1320 \mathrm{~cm}^{-1}$ (CS spectrum) was shifted to $1338 \mathrm{~cm}^{-1}$ in $\mathrm{C} 60$ spectrum, supporting the hypothesis of Maillard reaction at $60^{\circ} \mathrm{C}$ (Kosaraju et al., 2010). The absence of the characteristic peak of $\mathrm{N}-\mathrm{H}$ wag around $900 \mathrm{~cm}^{-1}$ in $\mathrm{C} 60$ spectrum also indicates amino group consumption.

Maillard reaction involves the condensation between an amino group and a reducing sugar and hence the release of a water molecule. This water formation may also affect sample C60, since the water content plays an important role on the porosity. During the drying process, pores are formed due to water evaporation. In the SEM images of C60, Figure 3b, d, "large spherical pores" can be observed. They were probably caused by "water-bubbles" evaporation. The effect of the drying temperature on the porosity of samples was also investigated by specific BET surface area and BJH specific pore volume analyses (Table 1). According to the rate of nitrogen adsorption by the samples, it is possible to estimate the specific surface area and the specific pore volume. As expected, sample C60 showed higher specific surface area and specific pore volume than C38. This may be due to the large water content and hence water evaporation during the drying process at $60{ }^{\circ} \mathrm{C}$. BET/BJH results are in accordance to SEM images of samples $\mathrm{C} 38$ and $\mathrm{C} 60$ (Figure 3). In these images, sample $\mathrm{C} 60$ showed large pores and higher number of pores than $\mathrm{C} 38$. In addition, both samples showed micro and nano-size interconnected pores.

It is important to mention that further than porosity, pore interconnections play a critical role in bone formation (Karageorgiou and Kaplan, 2005). Kuboki et al. (1998) studied three geometrically different forms of hydroxyapatite (solid particles, porous particles and porous tablets) to examine their effect on osteogenesis. The results indicated that the geometry of the interconnected porous structure creates spaces for vasculature that lead to osteogenesis, while the dense structure inhibits vascular formation and proliferation of cells, preventing bone formation (Kuboki et al., 1998). Indeed, porosity and pathways of pore interconnection have a strong impact on osteogenisis, since high porosity levels are necessary for bone matrix deposition in the empty spaces (Scaglione et al., 2012). In this regard, the use of biodegradable polymers, such as CS, associated to more-soluble forms of $\mathrm{CP}$ as bone substitutes allows the composite to initially support the mechanical stress and be re-absorbed over the time, opening space for new bone deposition (Penk et al., 2013). On the other hand, extremely high porosity and fast degradation may result in the loss of the surface that is needed for facilitation of bone formation (Bongio et al., 2010; Penk et al., 2013).

Surface topology (roughness) is another critical parameter in bone regeneration (Wennerberg et al., 1997). Deligianni et al. (2001) investigated the effect of surface roughness of hydroxyapatite on human bone marrow cell adhesion, proliferation, differentiation and detachment strength. They reported that surfacial roughness improved the response of bone marrow cells in vitro, probably due to the selective adsorption of serum proteins required for cell adhesion (Deligianni et al., 2001). Surficial SEM images of samples $C 38$ and $C 60$, Figure $3 a, b$, respectively, show the rough surfaces of these samples, formed by flakes and grain-shaped crystals, which are irregularly dispersed. This irregular crystal dispersion along with the surficial porosity make the surface of the samples rough and possibly adequate to cell adhesion. Liu et al. (2006) also studied the surface of calcium phosphate-chitosan composites as bone-substitute materials. They reported some flake-shaped crystals arrayed together and spread outside, forming flower clusters, while other crystals were isolated. We found similar crystal morphology; however, flower clusters were not found in C38 and C60 micrographs, probably due to the presence of other components in our samples, such as dextrose and citric acid. Particularly, the addition of these other components may increase the polarity (and hence hydrophilicity) of the composite by the introduction of carboxyl and hydroxyl groups. Then again, the enhancement of polarity may improve osteoblastic cell attachment to the samples (Deligianni et al., 2001).

Regarding to mechanical requirements for bone-grafts substitutes, an optimal balance between porosity (that is desired for osteogenesis) and mechanical properties, which is needed for osteointegration; is required to assurance successful implant. We studied the effects of drying temperature and period of drying on mechanical properties of the CS-CP composites (C38 and C60). According to Figure 4, an increase trend on compressive strength of sample C38 was observed, indicating that the extension of the drying period at $38{ }^{\circ} \mathrm{C}$ played an important role 
for improving the resistance to compression of this sample. It suggest that prolonged drying time at this temperature is required to slowly evaporate the water content. After 3 hours of demolded-drying, sample C38 showed no resistance to compression, probably due to the presence of water in the interior of this sample. On the other hand, prolonged period of drying at $60^{\circ} \mathrm{C}$ ( 72 hours) negatively affected the compressive strength of sample C60. It can be attributed to the increased porosity due to water formation (Maillard reaction) and fast water evaporation (bubbles) at this temperature.

The modulus of elasticity of C38 demolded-dried for 72 hours is superior to those of the bone-graft substitutes commercially available, such as Calcibon ${ }^{\circledR}$ (790 MPa), Norian SRS ${ }^{\circledR}(674 \mathrm{MPa})$ and $\mathrm{MIIG}^{\circledR}$ X3 (665 MPa) (Smulders et al., 2011). In addition, samples C60 demolded-dried for 24 hours showed modulus of elasticity comparable to those of commercial products. It is important to mention that these moduli were measured in air atmosphere and at room temperature. Thus, additional tests in water/body fluids at $37{ }^{\circ} \mathrm{C}$ must be performed in order to evaluate mechanical proprieties of CS-CP composites under bone-environmental conditions.

In regard of relative deformation, as expected, oppositely to compressive strength and modulus of elasticity, the highest percentage of elongation for both samples was measured after 3 hours. C 38 and C60 have cracked after being compressed by a strength slightly superior to the elastic limit. This behavior indicates deformation in the plastic region. According to Perren (2002), relative deformation up to $2 \%$ is tolerated by lamellar bone tissue, while three-dimensional woven bone tolerates up to $10 \%$ of deformation. Woven bone is formed after fractures or bone loss in order to quickly fill bone defects. It is gradually replaced by lamellar bone during the healing process (Perren, 2002). Thus, considering the implantation of the CS-CP composites in the bone defect, the woven bone would tolerate the relative deformation of samples C38 and C60 demolded-dried for 24, 48 and 72 hours. In addition, reduced relative deformation of the samples suggests dimensional stability that would facilitate the fixation of these composites in the bone defect. Further than reduced relative deformation, bone-graft substitutes should tolerate mechanical stress, which gradually increases along with the healing process (Romani et al., 2002). Considering compressive strength, modulus of elasticity and relative deformation, the sample C38 demolded-dried for 72 hours would be suitable for using as bone-graft substitute, due to its time-improved mechanical properties.
Nevertheless, biodegradability and osteoinductivity are other essential requirements for bone-grafts substitutes (Bonher et al., 2012). The use of $\beta$-tri-calcium phosphate that is more soluble than hydroxyapatite (Yamada et al., 1997) and chitosan, a lysozyme-biodegradable biopolymer (New et al., 2009), makes the CS-CP composite susceptible for bioresorption and biodegradation. Moreover, CS composites have been demonstrated osteoinductive effects (Jebahi et al., 2013; Kim et al., 2014; Kung et al., 2011) in vitro and in vivo. Thus, the CS-CP composites herein prepared are potentially biodegradable and osteoinductive, and demonstrated adequate porosity and mechanical properties for treating bone defects.

In summary, we successfully prepared mechanical properties-adjustable CS-CP composites for potential application as bone-graft substitutes. These CS-CP composites can be molded to any desired shape and showed dimensional stability after demolding. Mechanical properties of the composites can be improved by temperature and period of demolded-drying; therefore, they can be designed to support the mechanical needs of the lost bone. However, further in vitro and in vivo studies must to be performed for biocompatibility and bone regeneration evaluation.

\section{Acknowledgements}

This work was partially supported by the Fundação de Amparo a Pesqusisa do Estado de São Paulo FAPESP. The authors thank Dr. Cassio Ricardo Auada Ferrigno for allowing the use of Biomechanical facility and are thankful to the Centro Nacional de Pesquisa em Energia e Materiais - CNPEM/LNNano/LME for the support of scanning electron microscopy analysis.

\section{Reference}

Amini AR, Laurencin CT, Nukavarapu SP. Bone tissue engineering: recent advances and challenges. Critical Reviews in Biomedical Engineering. 2012; 40(5):363-408. http://dx.doi.org/10.1615/CritRevBiomedEng.v40.i5.10. PMid:23339648.

Armentano I, Dottori M, Fortunati E, Mattioli S, Kenny JM. Biodegradable polymer matrix nanocomposites for tissue engineering: a review. Polymer Degradation \& Stability. 2010; 95(11):2126-46. http://dx.doi.org/10.1016/j. polymdegradstab.2010.06.007.

Associação Brasileira de Normas Técnicas. NBR ISO 5833: implantes para cirurgia - cimentos de resina acrílica. Rio de Janeiro: ABNT; 2004.

Bongio M, van den Beucken JJJP, Leeuwenburgh SCG, Jansen JA. Development of bone substitute materials: from 'biocompatible' to 'instructive'. Journal of Materials Chemistry. 2010; 20(40):8747-59. http://dx.doi.org/10.1039/ c0jm00795a. 
Bonher M, Galea L, Doebelin N. Calcium phosphate bone graft substitutes: failures and hopes. Journal of the European Ceramic Society. 2012; 32(11):2663-71.

Bonjour JP. Calcium and phosphate: a duet of ions playing for bone health. Journal of the American College of Nutrition. 2011; 30(Suppl 5):438S-48S. http://dx.doi.org/10.1080/07 315724.2011.10719988. PMid:22081690.

Boskley AL. Bone composition: relationship to bone fragility and antiosteoporotic drug effects. BoneKEy Reports. 2013; 2:1-9.

Calori GM, Mazza E, Colombo M, Ripamonti C. The use of bone-graft substitutes in large bone defects: any specific needs? Injury. 2011; 42(Suppl 2):56-63. http:// dx.doi.org/10.1016/j.injury.2011.06.011. PMid:21752369.

Chung Y-C, Luo C-L, Chen C-C. Preparation and important functional properties of water-soluble chitosan produced through Maillard reaction. Bioresource Technology. 2005; 96(13):1473-82. http://dx.doi.org/10.1016/j.biortech.2004.12.001. PMid:15939275.

Dabrowski B, Swieszkowski W, Godlinski D, Kurzydlowski KJ. Highly porous titanium scaffolds for orthopaedic applications. Journal of Biomedical Materials Research. Part B, Applied Biomaterials. 2010; 95(1):53-61. http:// dx.doi.org/10.1002/jbm.b.31682. PMid:20690174.

Deligianni DD, Katsala ND, Koutsoukos PG, Missirlis YF. Effect of surface roughness of hydroxyapatite on human bone marrow cell adhesion, proliferation, differentiation and detachment strength. Biomaterials. 2001; 22(1):8796. http://dx.doi.org/10.1016/S0142-9612(00)00174-5. PMid: 11085388.

Hing KA, Wilson LF, Buckland T. Comparative performance of three ceramic bone graft substitutes. The Spine Journal. 2007; 7(4):475-90. http://dx.doi.org/10.1016/j.spinee.2006.07.017. PMid:17630146.

Hu MH, Lee PY, Chen WC, Hu JJ. Comparison of three calcium phosphate bone graft substitutes from biomechanical, histological, and crystallographic perspectives using a rat posterolateral lumbar fusion model. Materials Science and Engineering C. 2014; 45:82-8. http://dx.doi.org/10.1016/j. msec.2014.08.065. PMid:25491804.

Hutmacher DW. Scaffolds in tissue engineering bone and cartilage. Biomaterials. 2000; 21(24):2529-43. http://dx.doi. org/10.1016/S0142-9612(00)00121-6. PMid:11071603.

Jebahi S, Oudadesse H, Faouzi FZ, Elleuch J, Rebai T, Keskes H, Mostafa A, El Feki A. Osteoinduction and antiosteoporotic performance of hybrid biomaterial chitosan-bioactive glass graft: effects on bone remodeling. Journal of Material Science \& Engineering. 2013; 3(2):1-8.

Karageorgiou V, Kaplan D. Porosity of 3D biomaterial scaffolds and osteogenesis. Biomaterials. 2005; 26(27):547491. http://dx.doi.org/10.1016/j.biomaterials.2005.02.002. PMid:15860204.

Khan Y, Yaszemski MJ, Mikos AG, Laurencin CT. Tissue engineering of bone: material and matrix considerations. Journal of Bone and Joint Surgery. 2008; 90(Suppl 1):36-42. http://dx.doi.org/10.2106/JBJS.G.01260. PMid:18292355.
Kim S, Bedigrew K, Guda T, Maloney WJ, Park S, Wenke J, Yang YP. Novel osteoinductive photo-crosslinkable chitosan-lactide-fibrinogen hydrogels enhance bone regeneration in critical size segmental bone defects. Acta Biomaterialia. 2014; 10(12):5021-33. http:/dx.doi. org/10.1016/j.actbio.2014.08.028. PMid:25174669.

Kosaraju SL, Weerakkody R, Augustin MA. Chitosanglucose conjugates: influence of extent of Maillard reaction on antioxidant properties. Journal of Agricultural and Food Chemistry. 2010; 58(23):12449-55. http://dx.doi.org/10.1021/ jf103484z. PMid:21067178.

Kuboki Y, Takita H, Kobayashi D, Tsuruga E, Inoue E, Murata M, Nagai N, Dohi Y, Ohgushi H. BMP-induced osteogenesis on the surface of hydroxyapatite with geometrically feasible and nonfeasible structures: topology of osteogenesis. Journal of Biomedical Materials Research. 1998; 39(2):190-9. http:// dx.doi.org/10.1002/(SICI)1097-4636(199802)39:2<190::AIDJBM4>3.0.CO;2-K. PMid:9457547.

Kung S, Devlin H, Fu E, Ho K-Y, Liang S-Y, Hsieh Y-D. The osteoinductive effect of chitosan-collagen composites around pure titanium implant surfaces in rats. Journal of Periodontal Research. 2011; 46(1):126-33. http://dx.doi. org/10.1111/j.1600-0765.2010.01322.x. PMid:21108645.

Li J, Baker BA, Mou X, Ren N, Qiu J, Boughton RI, Liu $\mathrm{H}$. Biopolymer/calcium phosphate scaffolds for bone tissue engineering. Advanced Healthcare Materials. 2014; 3(4):469-84. http://dx.doi.org/10.1002/adhm.201300562. PMid:24339420.

Liu H, Li H, Cheng W, Yang Y, Zhu M, Zhou C. Novel injectable calcium phosphate/chitosan composites for bone substitute materials. Acta Biomaterialia. 2006; 2(5):557-65. http://dx.doi.org/10.1016/j.actbio.2006.03.007. PMid:16774852.

Madihally SV, Matthew HWT. Porous chitosan scaffolds for tissue engineering. Biomaterials. 1999; 20(12):113342. http://dx.doi.org/10.1016/S0142-9612(99)00011-3. PMid:10382829.

Martino AD, Sittinger M, Risbud MV. Chitosan: a versatile biopolymer for orthopaedic tissue-engineering. Biomaterials. 2005; 26(30):5983-90. http://dx.doi.org/10.1016/j. biomaterials.2005.03.016. PMid:15894370.

Moshiri A, Oryan A. Role of tissue engineering in tendon reconstructive surgery and regenerative medicine: current concepts, approaches and concerns. Hard Tissue. 2012; 1(2):1-11. http://dx.doi.org/10.13172/2050-2303-1-2-291.

New N, Furuike T, Tamura H. The mechanical and biological properties of chitosan scaffolds for tissue regeneration templates are significantly enhanced by chitosan from gongronella butleri. Materials (Basel). 2009; (2):374-98.

Oryan A, Alidadi S, Moshiri A. Current concerns regarding healing of bone defects. Hard Tissue. 2013; 26(2):1-12.

Penk A, Förster Y, Scheidt HA, Nimptsch A, Hacker MC, Schulz-Siegmund M, Ahnert P, Schiller J, Rammelt S, Huster D. The pore size of PLGA bone implants determines the de novo formation of bone tissue in tibial head defects in rats. Magnetic Resonance in Medicine. 2013; 70(4):925-35. http://dx.doi.org/10.1002/mrm.24541. PMid:23165861.

Perren, SM. Evolution of the internal fixation of long bone fractures: the scientific basis of biological internal fixation: 
choosing a new balance between stability and biology. The Bone \& Joint Journal. 2002; 84(B):1093-110.

Pillai CKS, Paul W, Sharma CP. Chitin and chitosan polymers: chemistry, solubility and fiber formation. Progress in Polymer Science. 2009; 34(7):641-78. http://dx.doi.org/10.1016/j. progpolymsci.2009.04.001.

Rinaudo M. Chitin and chitosan: properties and applications. Progress in Polymer Science. 2006; 31(7):603-32. http:// dx.doi.org/10.1016/j.progpolymsci.2006.06.001.

Romani WA, Gieck JH, Perrin DH, Saliba EN, Kahler DM. Mechanisms and management of stress fractures in physically active persons. Journal of Athletic Training. 2002; 37(3):306-14. PMid:16558676.

Scaglione S, Giannoni P, Bianchini P, Sandri M, Marotta R, Firpo G, Valbusa U, Tampieri A, Diaspro A, Bianco P, Quarto R. Order versus disorder: in vivo bone formation within osteoconductive scaffolds. Scientific Reports. 2012; 2(274):1-6. PMid:22355786.

Smulders E, van Lankveld W, Laan R, Duysens J, Weerdesteyn V. Microstructure and biomechanical characteristics of bone substitutes for trauma and orthopedic surgery. BMC Musculoskeletal Disorders. 2011; 12(34):1-14. PMid:21199576.

Spin-Neto R, Pavone C, Freitas RM, Marcantonio RAC, Marcantonio-Júnior E. Biomateriais à base de quitosana com aplicação médica e odontológica: revisão de literatura. Revista de Odontologia da UNESP. 2008; 37(2):155-61.
Sumner-Smith G. Bone in clinical orthopedics. 2nd ed. Dübendorf: AO Publishing; 2002.

Umemura K, Kawai S. Modification of chitosan by the Maillard reaction using cellulose model compounds. Carbohydrate Polymers. 2007; 68(2):242-8. http://dx.doi. org/10.1016/j.carbpol.2006.12.014.

Venkatesan J, Vinodhini PA, Sudha PN, Kim S-K. Chitin and chitosan composites for bone tissue regeneration. Advances in Food and Nutrition Research. 2014; 73:59-81. http://dx.doi.org/10.1016/B978-0-12-800268-1.00005-6. PMid:25300543.

Wennerberg A, Ektessabi A, Albrektsson T, Johansson C, Andersson B. A 1-year follow-up of implants of differing surface roughness placed in rabbit bone. The International Journal of Oral \& Maxillofacial Implants. 1997; 12(4):48694. PMid:9274077.

Yamada S, Heymann D, Bouler J-M, Daculsi G. Osteoclastic resorption of calcium phosphate ceramics with different hydroxyapatite/ $\beta$-tricalcium phosphate ratios. Biomaterials. 1997; 18(15):1037-41. http://dx.doi.org/10.1016/S01429612(97)00036-7. PMid:9239465.

Zhang Y, Zhang M. Three-dimensional macroporous calcium phosphate bioceramics with nested chitosan sponges for load-bearing bone implants. Journal of Biomedical Materials Research. Part A. 2002; 61(1):1-8. http://dx.doi.org/10.1002/ jbm.10176. PMid:12001239.

\footnotetext{
Authors

Guilherme Maia Mulder van de Graaf ${ }^{1}$, Andre Luis do Valle De Zoppa ${ }^{1}$, Rodrigo Crispim Moreira ${ }^{1}$, Sylma Carvalho Maestrelli ${ }^{2}$, Rodrigo Fernando Costa Marques $^{3}$, Maria Gabriela Nogueira Campos ${ }^{2 *}$

${ }^{1}$ Department of Surgery, School of Veterinary Medicine and Animal Science, Universidade de São Paulo - USP, São Paulo, SP, Brazil.

${ }^{2}$ Institute of Science and Technology, Universidade Federal de Alfenas - UNIFAL, BR 267 Km, 533, Rodovia José Aurélio Vilela, 11999, Cidade Universitária, CEP 37715-400, Poços de Caldas, MG, Brazil.
}

${ }^{3}$ Institute of Chemistry, Universidade Estadual Paulista "Julio de Mesquita Filho" - UNESP, Araraquara, SP, Brazil. 